\title{
教育講演
}

\section{8. 甲状腺機能異常の成因と治療}

\section{虎の䦐病院内分泌代謝科紫芝望琶}

Key words：甲状腺機能应症，甲状腺機能低下症，無痛性甲状腺苂，TSH不応症

\section{はじめに}

この稿では甲状腺機能異常を広義にとらえて， 甲状腺ホルモンの分泌から末梢作用までの間で異 常のあるものを全て含むものと定義する．表に甲 状腺機能異常の範囲と種類をまとめる。機能異常 の自然の原因は主として自己免疫異常と, 刺激伝 達系の異常で，ホルモン過剩を伴うものの代表格 としてバセドウ病，ホルモン欠走を伴いうるもの の代表として慢性甲状腺炎が挙げられる。慢性甲 状腺炎には無痛性甲状腺炎という, 特殊な病熊が あるが，これは慢性甲状腺炎に限らず，バセドウ 病の経過の途中にも出現して, 再発と紛らわしい ことがある。バセドウ病によるもの以外の甲状腺 腫をともなう甲状腺機能え進をプランマ一病とい うが，最近，一部の症例にTSH受容体や $G$ 蛋白の 異常による機能亢進が相次いで発見され，今後プ
ランマー病の病因が次々に明らかにされると想像 される.

\section{1. 甲状腺機能異常の検査}

甲状腺疾患の分類は，甲状腺の触診による形態 の特徵と, 血中甲状腺ホルモン濃度の二つに基づ いて行われる．現在の甲状腺ホルモンに関する検 查は軽度な異常症の発見にも有力なものとなって いて，遊離サイロキシン，遊離トリヨードサイロ ニン，高感度TSHの三つを測定することで，機能 状態の診断はほほ確実に行うことが出来る。その 他の検查は，それぞれ理由があるときに行われる べきもので，始めにはこの三者の検査で機能異常 の有無を検討し，更に検查を進める段階で次の検 查を行うのが望ましい.

表.

\begin{tabular}{|c|c|c|}
\hline 因 & ホルモン過剩 & ホルモン欠を \\
\hline 自己免疫異常 & $\begin{array}{l}\text { バセドウ病 } \\
\text { 無痛性甲状腺灸 }\end{array}$ & $\begin{array}{l}\text { 慢性甲状腺炎・萎縮性甲状腺炎 } \\
\text { 無痛性甲腺炎 }\end{array}$ \\
\hline 刺激伝垟の買常 & 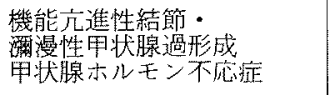 & TSH不店症 \\
\hline ヨード輸送体の異常 & & 置位性甲状腺機能低下症 \\
\hline $\begin{array}{l}\text { 感染による破壞 } \\
\text { 組織形成の異常 } \\
\text { 外涯入 }\end{array}$ & $\begin{array}{l}\text { 亜急性甲状腺炎 } \\
\text { ハンバーガー甲状腺中起症 }\end{array}$ & $\begin{array}{l}\text { 亜急性甲状腺炎 } \\
\text { クレチン症 }\end{array}$ \\
\hline
\end{tabular}




\section{2. 自己免疫異常に基づく甲状腺機能異常}

\section{1）慢性甲状腺炎と関連疾患}

（1）頻度：種々の方面から検索すると，剖検で は女性の $5 \sim 15 \%$, 男性の1〜5\%にリンパ球浸 潤など自己免疫異常を示す形態学的変化が見ら れ，血中のサイログロブリン抗体やミクロソーム 抗体加ら見ると，女性の10 13\%，男性の3\%に は抗体陽性で自己免疫性甲状腺異常があると想像 される。この頻度は加齢とともに上昇し，70歳以 上では女性の $33 \%$ に達するという報告もある。自 己免疫性甲状腺異常の代表は慢性甲状腺炎である が潜在性甲状腺機能低下症の頻度は 8 17\%に達 する．年齢と人口 1000 人あたりの甲状腺疾患の有 病率を見たイギリスのWhickhamの調査報告で は, 甲状腺機能立進症の頻度は中年以降, あまり 変わらないのに, 甲状腺機能低下症の頻度は加齢 とともに急激な増加を示し70歳代で1.4\%に達し て扝り，高齢者で甲状腺機能低下症が多いことが 注目される 度が高いものと推定される。潜在性機能低下症と はfree T4とfree T3が正常なのにTSHのみが上 昇している段階をいうもので，もっとも軽微な甲 状腺機能低下症と考えられる。

（2）潜在性甲状腺機能低下症：この病態は抗甲

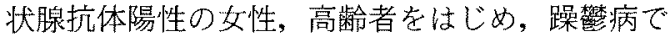
リチウム治療を受けている人たち, Down症候群, 成長ホルモン治療中の小児など, 多種多様なpopulation加発見されている。潜在性甲状腺機能低 下症が明らかな状腺機能低下症に進展する率も $50 \%$ 以上と報告され，顕在化すれば治療が必要で あるから，TSHの高感度測定は是非高龄者検診に 取り入れられて良い項目である.TSHが低下して いた場合，もちろん潜在性甲状腺機能立進症の可 能性があるが，重症な疾患が合併していたり，ド パミン系の強心薬が使われているとTSHは低下 するので治療を考慮する前に䛦断をよく確かめる 必要がある。

甲状腺機能低下症の治療には現在では甲状腺末
を使うことはほとんどなくなり，サイロキシンナ トリウムの製剤を 1 日 $2 \mu \mathrm{g} / \mathrm{kg}$ 使用するのが標準 である。娃娠前半期にはホルモンの必要量が約 $25 \%$ 堌加する。乫煙は甲状腺ホルモンの合成を障 害するのみでなく甲状腺ホルモンの作用にも障害 を及ぼすことが知られている゙．

（3）無痛性甲状腺炎：慢性甲状腺炎の患者はそ の経過中に無痛性甲状腺炎のエピソードを起こす ことがある。これは血中甲状腺ホルモンの上昇， TSHの低下を伴う点ではバセドウ病に似ている が，放射性ヨード甲状腺摂取率は低下していて， ホルモンの上昇は組織の炎症性破壊による漏出て ある。数週間のうちに自然に軽快する。バセドウ 病と正確な鑑別は放射性ヨード甲状腺摃取率によ る。バセドウ病では放射性ヨード甲状腺摄取率は 増加するが，無痛性甲状腺炎では減少する。この 病態はグルココルチコイドが急激に変化するとき に好んで発生し,クッシング症候群の手術後に起 こる例が本邦から世界に先駆けて報告された。 我々は下垂体機能低下症や下垂体手術に続発した 例を多く経験したが下垂体腫湟手術後に生じたク リーゼではないかと考えられるような例もあり， 下垂体一副腎系の防御機構が落ちているときの甲 状腺ホルモン過剩であるだけに，ショックなど重 大な結果を生む可能性もあり注意したい病態であ る。

（4）甲状腺萎縮，甲状腺機能低下の原因：慢性 甲状腺炎はしばしば甲状腺の萎縮, 甲状腺機能低 下に進展する疾患であるが，これはFas・FasLigand (FASL) により甲状腺細胞のapoptosisが 起こることによることが明らかにされた 腺細胞には本来, FASLが発現しているが, 自己免 疫異常の結果, IL-1などのサイトカインにより Fasが細胞膜に発現し，これが他の甲状腺細胞や， リンパ球なぞが表面に提示しているFASLを認識 すると細胞がapoptosisを起こす。Fas/FASLによ る細胞死は劇症肝炎の原因として有名であるが， 慢性甲状腺炎でもこのような機序が働いているこ とが，内外の研究者から報告された。 


\section{2) バセドウ病}

（1）バセドウ病の実験モデルと新しい病因論： バセドウ病甲状腺機能元進症については新しい実 験モデル，新しい考え方がKohnらのグループから 報告された。バセドウ病の患者には高頻度にTSH 受容体抗体が検出され，甲状腺機能方進はTSH受 容体に対する刺激性抗体で起こると想像されてい る.このことから, 当然, TSH受容体の色々な部 分を動物に免疫してバセドウ病の動物モデルを作 る試みはこれまでいくつもなされてきたが，長期 間の機能六進を確実に作るには至らなかった。千 葉大学の下条らがNIHのKohnのグループで研究 した報告によれば，マウスの線維芽細胞に抗原提 示構造であるMHC (Major Hystocompatibility Complex)クラス II とTSH受容体を発現させ，こ の線維芽細胞をマウスに注入すると，マウスの免 疫機構にTSH受容体抗原が提示されて, TSH受 容体抗体の增加，甲状腺の肥大，血中甲状腺ホル モンの増加を来す，といゔ).TSH受容体のみ，ま たはMHCクラスIIのみを提示した線維芽細胞で は，このような異常を起こすことは出来ない。こ の機序として,Kohnらは甲状腺細胞培養系を研究 し，甲状腺細胞では本来自己免疫が起きないよう に，細胞が刺激されてホルモン合成が高まるとき には，TSH受容体やMHCクラス IもIIも発現が 低下するように転写因子で調節されるのが，転写 因子が発現低下に作用するとこるに障害がある と，MHC-クラス I など抗原提示装置と同時に TSH受容体蛋白, TG (Thyroglobulin), TPO (Thyroid Peroxidase) が増加し，抗体産生機構に 提示され，抗TSH受容体抗体が産生される結果に なると説明している。転写因子がうまく作用しな い原因としてC型肝炎やHTLV-1などある種の RNAウイルスとの相互作用が関係あるだろうと 推論されている。メルカゾールやヨードは甲状腺 細胞に作用してMHCクラスIの発現を抑制する ように働くことも明らかにされだ5.

（2）抗甲状腺㨈：メルカゾールやPTUには主 としてヨードがサイログロブリンに有機化される ところに作用してホルモン合成を阻害する作用が
知られているが，メルカゾールにはヨードととも に甲状腺細胞でのMHCクラス I の発現抑制とい う意味や明らかにされた. PTUにはこのような作 用は知られていない. PTUは胎盤や乳汁への通過 性が低いことから，妊娠・授乳中の甲状腺機能方 進症に好んで使用されるが, 肝障害, 特に劇症朋 炎を誘発する場合のあることを我々は経験してい るので, 肝機能の詳細なチェックと軽度でも異常 のある場合には早期に治療を切り替える注意が必 要である．抗甲状腺郕と同時にサイロキシンなど 甲状腺ホルモン製剤を使用する治療法注block and replacement therapyとしてアレキサンダー ら，尾形らにより行われて来たが信州大学の橋爪 らはこの治療が受容体抗体を抑制し，再発も防ぐ 効果がある，と報告した．その後各国で行われた 追試ではこの効果については否定するものが多 い. block and replacement therapyは抗甲状腺 剤治療中の甲状腺ホルモン欠之を予防しうること は確かで，ホルモン製剤の量が補充量の範囲なら ば甲状腺ホルモン濃度の動摇の激しい症例に対し ては実施上便利な治療であるといえる。

（3）バセドウ病合併症の病因：バセドウ病には しばしば眼球突出症・限局性粘液水腫が合併する ことがある。我々はこれが組織中にグリコサミノ グリカン・プロテオグリカンが増加した結果によ る病態であることを証明し，特に大きなサイズの プロテオグリカンが増加していることを示してき た。プロテオグリカンには数種類有りそれぞれ 別々のサイトカインで增加する事も示した6). 最 近，眼窝，皮膚の線維芽細胞がTSH受容体を発現 していて，受容体抗体から刺激を受けとりうる可 能性が示された7)。これが眼简や皮䖉においてプ ロテオグリカンの合成增加を起こ主機序のうち， 主要なものであるかどうか現在研究中である。

\section{3. 刺激伝達系の異常による甲状腺機能異 常}

最近新しい事実が相次いで明らかにされてきた 領域の一つにTSH受容体から始まる刺激伝達系 
があるが，その一つとしてTSH受容体の変異によ りこの系がスイッチオンになった状態で甲状腺機 能え進症が起こることが示された。

1）機能元進性腺腫：そのうちの一つは機能立 進性腺腫で，TSH受容体をコードする遺伝子の somatic mutationによる ${ }^{8}$. 機能六進性腺腫には $\mathrm{TSH}$ 受容体とカップルするGs $\alpha$ 蛋白をコードす る遺伝子の変異によるものもあるが，これよりも 受容体の変異によるものの方が頻度が高い. 本邦 の報告では日本では両者ともあまり頻度は高くな いと報告されてきたが最近は異常が発見されたと の報告が増えてきている。

2）機能元進性甲状腺過形成：もう一つの形は 北フランスから報告されたびまん性甲状腺腫を伴 う, 自己免疫異常とは無関係の遗伝性甲状腺機能 穴進症で, TSH受容体の膜貫通部分の近くに変異 が発見されている9?.

3）ヨードと刺激伝達系の異常による甲状腺機 能異常：TSHの刺激伝達機構の変異により機能 亢進になっている例はヨードによる抑制がかかり にくく、ヨード過剩の状態では甲状腺ホルモンが 過剩に産生され, ヨードバセドウ状態像を呈する。 この特徵は，現在のところ原因の分からない腺腫 様甲状腺腫や機能六進性腺腫にも共通に認められ る現象で，TSH刺激伝達系のうち，TSH受容体， $\mathrm{Gs} \alpha$ 上り末梢の部分に変珙などまだ知られていな い異常がある可能性があり，今後の砰究が集中さ れる領域の一つであるうと思われる。また，ヨ一 ド久乏状態が長く続くと, 孤立性腺腫, 多発性腺 腫, 腺腫様甲状腺腫など甲状腺細胞の異常増殖に よる病態が出現するが，これらの病因の一部にも ヨードの欠乏により生ずる刺激伝達系の変異が含 まれる可能性があり，ここも今後の研究が集中さ れる領域の一つになるうと思われる。

3）TSH不应：TSH受容体蛋白がスウィッ チオフになった状態の変異も発見されている ${ }^{10)}$. これには症状があって遺伝性甲状腺機能低下症で あることによって発見されるものと, 症状はなく， 甲状腺ホルモンの血中濃度は正常であるがTSH の濃度が上昇している家族性，遺伝性異常から発
見されるものとがある。

4）甲状腺ホルモン不応症：最後に甲状腺ホル モン不応症について述へる。細胞核にある甲状腺 ホルモン受容体蛋白の一部の変異により生ずるも ので，レフェトフらの報告したこの疾患の初例は 臨床的に甲状腺ホルモン欠乏状態であるが，その 後の症例は必ずしもホルモン欠乏が目立たないも のが多い.甲状腺ホルモン受容体は組織によって 差があり，一部の組織では不応症で作用がなくて も，他の組織ではある程度の作用があることもあ り，動悸などを訴えることもある。臨床症状とし ては，知的発育の障害があることもないこともあ り，比較的大きな甲状腺腫があり，検査で甲状腺 ホルモンの増加とそれにも関わらず, TSHの増加 を認める.TSH産生腫瘍との鑑別が問題になるの で $\alpha$ subunitの測定は必須である.現在までのほと んどの症例は甲状腺ホルモン受容体のうち，TR$\beta$ と呼ばれるものの異常で変異の有無はDGGE (Denaturing Gradient Gel Electrophoresis) 法 という特殊な方法で検出する事も出来る。最近 TR- $\beta$ に異常はなく, nuclear cofactorの異常では ないかと推察される症例も報告されており，この 領域での新しい知見も今後蓄積されるに相違な $4^{111}$.

\section{4、ヨード輸送体の異常による甲状腺機能 低下症}

ごく最近，甲状腺細胞膜のヨード輸送担体であ る $\mathrm{Na}$ /I-symporterが単離されたが，この蛋白を コードする遺伝子の変異による家族性甲状腺機能 低下症が報告されている ${ }^{12}$.

以上，甲状腺機能異常に関する最近の知見を中 心にのべた。

\section{文 献}

1) Dayan CM et al: Chronic autoimmune thyroiditis. N Engl J Med 353: 98, 1996.

2) Muller B, et al: Impaired action of thyroid hormone associated with smoking in women with hypothyroidism $\mathrm{N}$ Engl J Med 333 : 964, 1995. 
3) Giordano $\mathrm{C}$, et al: Potential involvement of Fas and its ligand in the pathogenesis of $\mathrm{Ha}$ shimoto's thyroiditis. Science 275: 960, 1997.

4) Shimojo N, et al: Proc Natl Acad Sci USA 93: 11074, 1996.

5) Kohn LD: Transcription factors and autoimmune thyroid disease, The 1st congress of molecular thyroidology 16, 1997.

6) Imai $Y$, et al : Effect of cyclic AMP on hyaluronan and proteoglycan production by retroocular tissue fibroblasts in culture. Endocrine $\mathrm{J} 41: 645,1994$.

7) Heufelder A: Pathogenesis of Graves' ophthalmopathy : Recent controversies and progress. Eur J Endocrinol 132: 532, 1995.

8) Parma J, et al: Somatic mutations in the thyrotropin receptor gene cause hyperfunction- ing adenomas. Nature 365:649, 1993.

9) Duprez L, et al: Germline mutations in the thyrotropine receptor gene cause nonautoimmune autosonal dominant hyperthyroidism. Nature Genet 7:396, 1994.

10) Sunthornthepvarakui $T$, et al: Brief report: Resistance to thyrotropin caused by mutations in the thyrotroin receptor gene. New Engl J Med $332: 155,1995$.

11) Weiss RE, et al: Dominant inheritance of resistnace to thyroid hormone not linked to defects in the thyroid hormone receptor $\alpha$ or $\beta$ genes may be due to a defective cofactor J Clin Endocrinol Metab 81: 4196, 1996.

12) Fujwara $H$, et al., Congenital hypothyrojdism caused by a mutation in the $\mathrm{Na} / \mathrm{I}$-sympoter, Nature Genetics 16: 124, 1997. 